\title{
HUBUNGAN KOMUNIKASI ORGANISASI ANTAR PEGAWAI TERHADAP KINERJA PEGAWAI DINAS PARIWISATA KABUPATEN MAMASA
}

\author{
Marianus ${ }^{1}$, Abd. Asis ${ }^{2}$ \\ ${ }^{1}$ Prodi Ilmu Komunikasi, Fakultas Ilmu Sosial dan Ilmu Pemerintahan \\ Universitas Al Asyariah Mandar \\ Email: marianus1967@gmail.com \\ ${ }_{2}^{2}$ Prodi Ilmu Pemerintahan, Fakultas Ilmu Sosial dan Ilmu Pemerintahan \\ Universitas Al Asyariah Mandar \\ Email: abdasis1989@gmail.com
}

\section{ABSTRACT}

This study aims to determine the relationship of organizational communication, and to explain the process of employee performance, as well as communication barriers. The research is descriptive qualitative in nature to understand the phenomena that occur in the research subject with a phenomenological approach. Collecting data through observation, interviews, documentation study, literature study. The results showed that the organizational communication relationship between employees uses formal communication which is official model and can be done in groups or forums in the command line according to leadership communication. All employees cannot communicate directly to the leadership. The organizational communication relationship that occurs in the Mamasa Regency Tourism Office uses a top-down communication pattern and cross-channel communication. Some of the communication barriers are errors in the delivery of information from leaders to subordinates, semantic barriers, ambiguous barriers to communication between leaders and staff, physical barriers, and inability to convey information from the leadership to the staff.

\begin{abstract}
ABSTRAK
Penelitian ini bertujuan untuk mengatahui hubungan komunikasi organisasi, dan menjelaskan proses kinerja pegawai, serta hambatan komunikasi. Penelitian bersifat deskriptif kualitatif untuk memahami fenomena yang terjadi pada subjek penelitian dengan pedekatan fenomenologi. Pengumpulan data melalui observasi, wawancara, studi dokumentasi, studi pustaka. Hasil penelitian menunjukan bahwa hubungan komunikasi organisasi antar pegawai mengunakan komunikasi formal yang modelnya resmi dan bisa dilakukan dalam kelompok atau forum dalam garis perintah sesuai komunikasi
\end{abstract}


pimpinan. Semua pegawai tidak dapat melakukan komunikasi langsung kepada pimpinan. Hubungan komunikasi organisasi yang terjadi di Dinas Pariwisata Kabupaten Mamasa mengunakan pola komunikasi dari atas kebawah dan komunikasi lintas saluran. Beberapa hambatan komunikasinya adalah kesalahan penyampaian informasi dari pimpinan ke bawahan, hambatan semantik, hambatan yang mendua dalam komunikasi pimpinan dan staf, hambatan fisik, tidak sampainya informasi yang disampaikan pimpinan ke staf.

Kata Kunci: Komunikasi Organisasi, Kinerja, Pegawai.

\section{PENDAHULUAN}

Organisasi merupakan sebuah system sosial yang kompleksitasnya dapat terlihat melalui jenis, peringkat, bentuk dan jumlah interaksi yang berlaku. Proses pada organisasi merupakan satu aspek penentu untuk mencapai organisasi yang efektif. Salah satu proses yang akan selalu terjadi pada organisasi apapun adalah proses komunikasi. Melalui organisasi terjadi pertukaran informasi, gagasan, dan pengalaman. Mengingat perannya yang penting dalam menunjang kelancaran berorganisasi, maka perlu perhatian yang lebih serius dalam mengelola komunikasi dalam organisasi.

Proses komunikasi yang begitu dinamik dapat menyebabkan macam perkara yang mempengaruhi pencapaian sebuah organisasi terutama timbulnya salah faham dan perseteruan. Komunikasi memelihara motivasi, memberikan penerangan pada para pegawai mengenai apa yang wajib dilakukan, seberapa baik mereka mengerjakannya dan apa yang dapat di lakukan buat meningkatkan kinerja bila sedang berada di bawah standar (FarizRemanda, 2012)

Aktivitas komunikasi di perkantoran senantiasa disertai tujuan yang ingin dicapai. Budaya komunikasi pada konteks komunikasi organisasi harus dicermati berdasarkan berbagai sisi. Sisi pertama adalah komunikasi antara atasan kepada bawahan. Sisi kedua yaitu antara pegawai yang satu dengan pegawai yang lain. Sisi ketiga adalah antara pegawai kepada atasan. Masingmasing komunikasi tersebut memiliki pola masing-masing (Benny usman, 2013: 1-18).

Salah satu komponen yang sangat menentukan berhasil atau tidaknya kinerja Pegawai Dinas Pariwisata adalah diperlukan adanya komunikasi para personil pegawai baik dari internal maupun eksternal. Komunikasi memegang peranan yang sangat penting dalam suatu interaksi sosial, oleh karena itu berpengaruh dalam dunia kerja. 
Hubungan Komunikasi Organisasi Antar Pegawai terhadap Kinerja Pegawai Dinas Pariwisata Kabupaten Mamasa

Tempat kerja merupakan suatu ruang sosial yang menfokuskan pada peran dari komunikasi, sehingga aktivitas kerja bisa dioptimalkan. Penggunaan komunikasi baik secara verbal maupun non verbal berpengaruh cukup besar pada lingkungan kerja yang diwujudkan dalam visi dan misi dari organisasi. Secara tidak langsung dibutuhkan komunikasi yang efektif dalam menggerakkan jalannya organisasi.

Pentingnya komunikasi bagi manusia tidak dapat dipungkiri begitu juga halnya bagi suatu organisasi. Dengan adanya komunikasi yang baik maka suatu organisasi dapat berjalan lancar dan berhasil. Begitu juga sebaliknya, kurang atau tidak adanya komunikasi yang baik maka organisasi dapat mecet atau berantakan. Misalnya bila dalam suatu perkantoran, pegawai tidak memberi informasi kepada sesama pegawai maka kinerja pegawai tidak akan tercapai dengan baik.

Dengan demikian, komunikasi organisasi akan ikut menentukan baik buruknya kinerja pegawai, termasuk dalam hal ini terhadap Dinas pariwisata. Kondisi ini berarti pegawai Dinas Pariwisata memegang peranan penting untuk dapat memberikan iklim yang memungkinkan bagi Dinas Pariwisata Kabupaten Mamasa untuk bekerja dengan penuh semangat. Dengan komunikasi organisasi yang baik dapat membangun dan mempertahankan kinerja pegawai Dinas Pariwisata yang yang lebik baik.

Ukuran maju atau tidaknya organsiasi dipengaruhi oleh kuantitas, kualitas karya dan perilaku anggota organisasi yang ada di dalamnya. Setiap pegawai memiliki kinerja yang berbeda-beda. Hal ini disebabkan karena setiap individu memiliki kemampuan yang berbeda dalam hal menangkap suatu pengetahuan dan keterampilan. Selain sifat individu pegawai itu sendiri salah satu penyebab yang dapat berpengaruh terhadap kinerja pegawai Dinas Pariwisata adalah komunikasi organisasi. Kepala Dinas Pariwisata dan para pegawai lainya harus membuat jalur-jalur komunikasi ke bawah dan ke samping. Dengan demikian suasana terbuka, saling sinergi, terjalinnya komunikasi verbal dan non verbal dapat tercipta. Para pegawai Dinas Pariwisata pun akan bersemangat dalam melakukan kinerja karena komunikasi organisasi yang tercipta mendukung para pegawai untuk melakukan yang terbaik, karena adanya komunikasi organisasi yang baik. Dengan demikian komunikasi organisasi merupakan faktor pendukung terhadap kinerja Pegawai Dinas Pariwisata.

Komunikasi organisasi di kantor Dinas Pariwisata Kabupaten Mamasa terutama Kepala Dinas dan para pegawai Dinas Pariwisata yang ada di Mamasa menunjukkan komunikasi organisasi yang baik. Mengutamakan kerja sama yang baik antara Kepala Dinas dengan pegawai Dinas Pariwisata Kabupaten Mamasa, saling menghargai serta saling menyapa satu sama lain 
dan terjalinnya komunikasi yang baik di dalam lingkungan Dinas Pariwisata Kabupaten Mamasa.

Komunikasi merupakan sarana untuk mengadakan koordinasi antara aneka macam subsistem pada perkantoran. Menurut Kohler(2011:1) ada dua model komunikasi dalam meningkatkan kinerja dan mencapai tujuan perkantoran . Pertama, komunikasi koordinatif, yaitu proses komunikasi yang berfungsi untuk menyatukan bagian-bagian (subsistem) perkantoran. Kedua, komunikasi interaktif, ialah proses pertukaran informasi yang berjalan secara berkesinambungan, pertukaran pendapat dan sikap yang dipakai menjadi dasar penyesuaian di antara sub-sub sistem pada perkantoran, juga antara perkantoran dengan kawan kerja. Frekuensi dan intensitas komunikasi yang dilakukan juga turut mempengaruhi hasil berdasarkan suatu proses komunikasi tersebut.

Dalam hal komunikasi yang terjadi antar pegawai, kompetensi komunikasi yang baik akan mampu memperoleh dan mengembangkan tugas yang diembannya, sehingga taraf kinerja suatu organisasi (perkantoran) semakin baik. Dan sebaliknya, apabila terjadi komunikasi yang jelek dampaknya terjalinnya hubungan yang tidak baik, perilaku yang otoriter atau acuh, perbedaan pendapat atau konflik yang berkepanjangan, dan sebagainya, bisa berdampak dalam output kerja yang tidak maksimal.(Wirawan, 2008)

Peningkatan kinerja pegawai secara perorangan akan mendorong kinerja sumberdaya manusia secara keseluruhan dan memberikan feed back yang tepat terhadap perubahan perilaku, yang direflesikan dalam kenaikan produktifitas (Bandung Hasibuan, 2007)

DinasPariwisata Kota Mamasa merupakan salah satu organisasi formal di lingkungan aparatur pemerintah yang memberikan kontribusi yang cukup besar dalam embangunan khususnya Kabupaten Mamasa. Program-program kerja yang dirancang bertujuan untuk mempromosikan dan melindungi bidang kepariwisataan yang merupakan asset negara yang sangat penting. Sehingga sangat diharapkan kinerja optimal dapat diwujudkan melalui peranan komunikasi yang efektif agar dapat memenuhi peran dan fungsinya sebagai aparat pemerintah yang mengabdikan dirinya pada bangsa dan Negara ini.

\section{METODE PENELITIAN}

Metode dalam penelitian ini adalah kualitatif untuk menyajikan data yang akurat dan mendalam sehingga ketika dilakukan analisis akan diperoleh hasil yang sesuai dengan keadaan yang sebenarnya dari tempat penelitian di dinas Kabupaten Mamasa. 
Hubungan Komunikasi Organisasi Antar Pegawai terhadap Kinerja Pegawai Dinas Pariwisata Kabupaten Mamasa

Mengacu pada pendapat Moleong (2014) menyatakan bahwa penelitian kualitatif merupakan cara untuk mendeskripsikan dengan menggunakan katakata serta bahasa yang baik atas pemahaman tentang fenomena yang terjadi dan pengalaman yang dimiliki subjek penelitian seperti persepsi, perilaku, tindakan, motivasi, dan sebagainya, secara holistik.

Penelitian ini berusaha untuk memahami fenomena yang terjadi oleh subyek penelitian, maka pendekatan yang digunakan adalah fenomenologi. Fenomenologi adalah pandangan berfikir yang berfokus kepada pengalaman ubjektif manusia serta interpretasi-interprestasi dunia (Prastowo, 2012). Oleh sebab itu pendekatan fenomelogi digunakan untuk menggambarkan dan menjelaskan bagaimana pelaku dengan pengalamannya dan memahami bagaimana komunikasi yang terjadi di dinas pariwisata .

\section{HASIL PENELITIAN}

\section{Hubungan Komunikasi Organisasi antar Pegawai di Dinas Pariwisata Kabupaten Mamasa.}

Hubungan komunikasi organisasi atau instansi tentu wajib memiliki pola komunikasi organisasi, supaya instansi yang dipimpin bisa berjalan dengan baik dan sanggup mencapai tujuan. Yang dimaksud pola komunikasi adalah bentuk atau pola hubungan antara dua orang atau lebih dalam proses penerimaan pesan.

Dinas Pariwisata Kabupaten Mamasa khususnya pada satuan kerja procurement dan material management memakai pola komunikasi rantai karena bentuk komunikasi yang dilakukan secara formal dan bertahap. Ada beberapa taraf jabatan pada perusahaan ini, jabatan tertinggi berdasarkan kepala dinas ke specialist selanjutnya sekretaris manager dan terakhir sub bagian/seksi-seksi dan pembantu umum. Jika penyampaian liputan dari sub bagian atau seksiseksi harus melalui proses berdasarkan taraf jabatan yang rendah sampai tertinggi, dan tiak boleh pribadi ke kepala dinas dan proses penyampaian informasi itu melalui rapat.

Data yang ditemukan dilapangan memperlihatkan bahwa, pola komunikasi yang dilakukan antara pimpinan dengan pegawai ada 2 yaitu, secara formal dan secara struktural.

Komunikasi yang formal adalah proses komunikasi yang modelnya resmi dan bisa dilakukan dalam kelompok atau forum dalam garis perintah sesuai kepala instansi, dari susunan lembaga atau organisasi pelaku bisa berkomunikasi dengan petugas lembaga dengan status masing-masing, adapun komunikator yang 1 adalah komunikasi formal yang dilakukan dengan instansi 
dengan cara yang resmi yang dilakukan kepala instansi dengan pegawai. Hal ini dijelaskan oleh Kepala bidang Petrus Arief, S.Sos mengatakan bahwa:

"Jika kami ingin menyampaikan ide, gagasan, dan pendapat tentang perkembangan pariwisata lainya, biasanya kami menyampaikan sedikit demi sedikit kepada sekertaris dinas karena kami tidak bisa langsung ke pimpinan karena adanya strata jabatan di dalamnya" (Wawancara, 9 Juni 2020)

Kepala bidang mengatakan dalam komunikasi Formal dan terstruktur telah menjadi ketetapan peraturan dan berlaku di dinas Pariwisata Kabupaten Mamasa. Semua pegawai tidak dapat melakuakan komuniaksi langsung kepada kepala dinas, untuk dapat berkomuniaksi dengan kepala dinas bisa menggunakan perantara dikarenakan model yang digunakan adalah pola atau model rantai yakni terdapat langkah-langkah yang harus dilalui sebelumnya (Mediator) dalam penyampaian pesan yang ingin disampaiakan :

"Ketika saya ingin menyampaikan pelaporan saya ke kepala dinas saya wajib melapor dulu sama sekertaris dan sekertaris yang menyampaikan pesan saya kepada kepala dinas "(Wawancara, 9 Juni 2020)

Kalimat di atas dapat diartikan bahwa model kumunikasi secara formal yang berlaku di Dinas Pariwisata dalam satuan kerja procurement dan material management sudah berlaku secara efektif baik kepada pemimpin ataupun bawahannya. Karena pada dinas pariwisata telah memiliki tanggung jawab secara formal, alur komunikasi yang terarah antara kepala dinas, fungsional, sekretaris, dan staf.

Komunikasi menjadi salah satu alat bagi pemimpin untuk memberi perintah terhadap bawahannya, dikarenakan pemimpin mempunyai tiga tugas krusial yakni peran antar pribadi, informasional dan pengambil keputusan. Sebagai suatu instansi baik, swasta maupun nonswasta tentu memiliki model komunikasi untuk meraih tujuannya. Maksud dan tujuan adanya model seperti itu adalah untuk mengatur dan mengefektifkan tugas-tugas yang ada dalam sebuah instansi. Kemudian dari pada itu diharapkan kestabilan dalam menjalankan tugasnya, seperti yang dikatakan kepalah Bidang bahwa:

"Pada setiap unit sudah memiliki tugas masing masing sehingga setiap pegawai atau staf tidak bisa mencampuri urusan pekerjaan unit lain. Jadi kinerja pegawai bisa terstruktur dengan baik" (Wawancara, 9 Juni 2020).

Dari pernyataan kepala dinas tentang procuremen dan material manejemen dapat di artikan bahwa setiap pegawai yang bekerja pada difisi pariwisata kususnya di unit kerja pocureremen dan material manejemen telah memiliki tanggung jawap masing-masing yang tersusun pada instansi tersebut. Dalam organisasi pemerintahan memiliki tugas masing-masing yang berbeda 
Hubungan Komunikasi Organisasi Antar Pegawai terhadap Kinerja Pegawai Dinas Pariwisata Kabupaten Mamasa

yakni intruksi, penjelasan, laporan lisan, pembicaraan untuk memperoleh kabar supaya komunikasi dapat berhasil perlu memperhatikan pesan yang di sampaikan.

Pada unit kerja tenaga pakar memiliki tanggung jawap untuk memberi saran kepada kepala dinas mengenai tanggung jawap pada lingkup instansi, dan melakukan tanggung jawap dari sekretaris manager, seperti yang dikatakan spesialis (tenaga ahli) Hanna, S.Sos:

"Pada instansi ini saya sebagai fungsional wajib mengerjakan peSkerjaan sekertaris dinas saat tidak ada dan saat ada yang mau melapor ke kepala dinas wajib melalui sekertaris dinas dahulu." (Wawancara, 9 Juni 2020)

Menurut sekertaris kepala dinas, di saat sedang tidak di tempat dan pegawai yang mau berkomunikasi kepada kepala dinas wajip melalui sekertaris sebelum kepada kepala dinas:

"iya saya tidak perna terbebani saat menjalan tugas dari kepala dinas dan saya perna di beri tugas untuk keluar kota dalam melakukukan perjalanan dinas yang penting dan puji Tuhan saya bisa melaksanakan pekerjaan dengan sangat baik,dan kepala sangat puas dengan yang saya lakukan serta saya mendapat bonus, dan itu membuat saya lebih percaya diri karena mampu menuntaskan tanggung jawap itu dengan baik dan benar" ( Wawancara, 9 Juni 2020).

Informasi pada wawancara tersebut bisa di artikan bahwa model komunikasi rantai berdasarkan pemimpin ke pegawainya yang di lakukan kantor dinas parawisata kabupaten Mamasa, pada unit kerja pocuremen dan material manejemen telah berjalan baik dan sanggup menciptakan kepercayaan diri dalam bekerja terhadap kepala ataupun bawahannya Tugas dan tanggung jawap Sekertaris kepala dinas adalah membantu kepala dinas menjalankan tugasnya yakni aktifitas, pemasaran dan membuat laporan aktivitas dan berkordinasi untuk membuat/merancang kegiatan pemasaran sebagaimana yang di ungkapkan oleh Sekertaris Cynthia:

"Pada instansi ini ada sekertaris kepala dinas yang mana tugasnya yaitu melaksanakan koordinasi kontrak dengan instansi lainnya, membuat surat undangan,permohonan serta membantu keuangan dan perencanaan untuk mengadakan barang yang di butuhkan dinas parawisata" (Wawancara, 9 Juni 2020)

Dari analisis penulis, dalam dinas pariwisata, sekretaris telah melakukan tanggung jawabnya selaku sekretaris kepala dinas sebagaimana mestinya. itu terihat jelas dari prospek pekerjaan Dinas pariwisata Kabupaten Mamasa. Staff dinas Pariwisata Kabupaten mamasa memiliki tanggung jawab untuk mencari dan mengumpulkan data mengolah data dan melakukan tanggung jawab yang 
diberikan oleh kepala dinas serta membuat arsip data data yang masuk dan keluar dari dinas pariwisata kabupaten mamasa

Proses komunikasi yang ada pada lingkup Dinas Pariwisata Kabupaten Mamasa tak terlepas dari kerja sama yang mereka laksanakan secara strutural. Adanya langkah langkah untuk mengambil keputusan adalah dengan melakukan kedap kerja supaya rangcangan kerja Dinas Pariwisata bisa dilaksanakan dengan baik sehingga tidak terjadi kesalahan pada komunikasi sehingga tujuan dari dinas bisa dapat benar benar terwujud. Seperti yang dikatakan oleh Kepala Bidang Avival Putra,S.Sos bahwa:

"Misal ada perkara dan perkara itu adalah kepentingan dinas pariwisata dan itu berkaitan dengan instansi maka yang dilakukan adalah kita berbicara dan bertemu dengan pimpinan secara formal. Dalm pertemuan itu kami sebagai staf bebas memberikan pendapat yang ditampung oleh notulen dan diselesaikan dengan kesepakan bersama yang disetujui oleh semua pihak demi kelancaran kerja dinas"(Wawancara, 9 Juni 2020).

Pesan terarah dapat dilakukan pada sebuah instansi pemerintahan, yakni berdasarkan atasan kebawah atau berdasarkan pimpian kebawahan, ataupun sebaliknya, bisa juga secara horizontal atau berdasarkan samping yakni pihak yang jabatannya sama suatu instansi atau organisasi dinas pariwisata.akan tetapi arus atau model komunikasi yang dilakukan pada instansi pemerintahan lebih condong dari atas kebawah atau atasan ke bawahan. Komunikasi itu berupa pengarahan, instruksi, penjelasan, dan sebagainya seperti yang telah dijelaskan Kepalah Bidang Alfredi, SE., M.Si bahwa

"Ketika akan ada rapat kerja saya memperoleh kabar dari teman atau langsung pimpinan sehingga saya sanggup mendapatkan catatan tentang pekerjaan atau staf mampu memeperoleh keterangan dibidang kerja sehingga dapat memberikan kritikan dan pendapat kepada kepala dinas "( Wawancara, 9 Juni 2020)

Arviniral Putra, S.Sos menilai bahwa keterangan yang didapatkan menurut pimpinan berdasarkan rapat kerja, setelah itu fungsional menyampaikan kepada staff Peneliti menyimpulkan bahwa, komunikasi dari atas kebawah lebih effektif karena dalam sebuah organisasi pemerintah sebagai penentu kelangsungan kegiatan yang sudah dirancang, dikarenakan pemimpinlah yang memberi perintah, atau arahan yang wajib dikerjakan.komunikasi dari atas kebawah yaitu pesan atau amanat dari pimpinan ke bawahan, seperti melakukan perintah dari pimpinan Dinas Pariwisata. Sebagaimana Kepala Bidang Petrus Arief,S.Sos mengungkapkan: 
Hubungan Komunikasi Organisasi Antar Pegawai terhadap Kinerja Pegawai Dinas Pariwisata Kabupaten Mamasa

"Pekerjaan yang ada di kantor ini atas dasar perintah pimpinan sudah sesuai dengan bidang pekerjaan masing-masing sehingga dapat selesai dengan tepat waktu" (Wawancara, 9 Juni 2020)

Saat melakukan pekerjaan sangat dibutuhkan komunikasi dari atas kebawah mengingat tanpa perintah atau arahan kita tidak bisa melakukan pekerjaan dan tdk akan selesai sesuai waktu yang direncanakan

Komunikasi berdasarkan atas ke bawah atau kepala dinas ke staff Pariwisata biasanya bisa berupa arahan dan perintah dari kepala dinas dalam unit kerja dinas pariwisata kabupaten mamasa agar target yang dirancang mendapat output yang maksimal seperti yang diumgkapkan staf maikal:

"Saya sebagai staff umum di dinas Pariwisata ini memiliki kesempatan untuk membeberkan dan memberikan keluhan ,serta saran untuk perkembangan instansi kedepannya" (Wawancara, 9 Juni 2020).

Hubungan formal ke bawah yaitu komunikasi yang berlangsung dari kepala dinas kepada staff, yaitu komunikasi dari ketua dinas dan sekretaris kepala dinas yang membicarakan pada staff. Komunikasi formal ke bawah cocok dipakai bila keputusan-keputusan itu bersifat instruksi atau pengarahan. Selain perintah dan instruksi, hubungan formal ke bawah pula berisi berita mengenai tujuan organisasi, kebijakan-kebijakan, peraturan, dan akhirnya bisa mendapat umpan pulang balik aplikasi tugas mereka. Dengan demikian pelaksanaan komunikasinya mengikuti arus jabatan kewenangan yang tergambar pada struktur organisasi. Kewenangan inilah menjadi sistem kerja yang menyediakan saluran-saluran dimana mekanisme kerja, istruksi, dan gagasan serta umpan kembali mengenai aplikasi tugas- tugas dapat disalurkan.

Komunikasi adalah hal yang sangat penting dan mengikat kesatuan organisasi. Komunikasi membantu anggota-anggota organisasi untuk mencapai tujuan individu dan juga organisasi, merespon dan mengimplementasi perubahan organisasi, mengoordinasikan kegiatan organisasi, dan ikut memainkan peran dalam hampir semua tindakan organisasi yang relevan. Berdasarkan wawancara dalam galat satu staff Dinas Pariwisata, maka diperoleh suatu konklusi bahwa komunikasi yang bersifat formal lebih seringkali mereka gunakan agar hubungan yang mereka lakukan tetap menghargai mekanisme dan aturan pekerjaan yang telah ditetapkan oleh perusahaan. Seperti halnya yang dikatakan oleh kepala bidang Petrus Arief, S.Sos:

"Sebagai staf, komunikasi kami dengan pimpinan dinas,kami kami menggunakan komunikasi pada tempat dan saat yang tepat seperti saat formal karna komunikasi formal pada saat kerja adalah bukti rasa hormat 
kami kepada pemimpin dimana sebagai pejabat tertinggi didinas" (Wawancara, 9 Juni 2020).

Dari wawancara kepala bidang Petrus Arief mengatakan bahwa hubungannya kepada staff dinas pariwisata sangat baik, ini dikarenakan pemimpin seoranag yang ramah dan mudah akrab terhadap staff yang aktif.hubungnan kedekatan kepala dinas dan para staf dinas ini dibuktikan dengan tidak adanya kegiatan familiy atau keluarga ghatering. Hal ini dilakukan sebagai galay satu upaya buat memajukan organisasi dan meningkatkan kinerja instansi, sehingga tujuan komunikasi bisa terwujud.

Melaksanakan suatu model komunikasi antara pemimpin dan pegawai, sebab dengan menjalin suatu hubungan yang baik diharapkan komunikasi yang lebih baik pula agar pegawai atau staff dinas pariwisata bisa lebih berkembang kedepannya. Seperti yang diungkapkan oleh kepala dinas Rahmat, S.sos :

"Iya pada jam istirahat saya biasanya menjalin keakraban kepada sesama penghuni kantor,berbincang-bincang walaupun tidak direncanakan contohnya saat di kantin, atau saat menjenguk kerabat rekan kerja yang sakit maupun ketika bertemu dijalan saya tidak sungkan untuk menyapa" (Wawancara, 9 Juni 2020).

Kepala dinas dan para pegawai adalah dua faktor yang sangat krusial yang tidak dapat di pisahkan dalam lingkup dinas pariwisata kabupaten mamasa, kedua pihak memiliki tempat atau posisiyang saling melengkapi satu dengan yang lainnya.seperti pada organisasi keterbukaan antara pemimpin dan staff itu perlu. Seperti yang diungkapkan kepalah dinas Rahmat, S.Sos bahwa :

"Dalam lingkup dinas pariwisata keterbukaan sangat penting,sebab keterbukaan bisa membantu dalam pemecahan masalah unit kerja, namun hal sepatutnya dirahasiakan harus tetap dirahasiakan sebab ada hal yang tak dapat diketahui oleh staf atau orang lain. Seperti keterbukaan dalam organisasi seperti transparansi tentang pelaksanaaan tender. Dan keterbukann ini diharapkan sinkton dari masing masing staf sehingga pekerjaana bisa berjalan dengan baik. Dari keterbukaan ini ada kerja sama dan kesadaran tanggung jawab dalam melakukan tanggung jawab yang di perintahkan" (Wawancara, 9 Juni 2020).

Berdasarkan wawancara tersebut, kepala dinas Pariwisata Kabupaten Mamasa sangat terbuka menggunakan para stafnya pada hal pemberitaan warta mengenai kerja sama. Di sini jelas bahwa di dalam satuan kerja procurement dan material management, menganggap bahwa keterbukaan antara kepala dinas dan para staff sangat penting, mengingat tanpa ada keterbukaan maka tidak akan terdapat rasa saling percaya diantara mereka. 
Dinas Pariwisata dalam satuan kerja procuurement dan material management melakukan suatu pola komunikasi organisasi agar mampu membangun suatu komunikasi yang aman sehingga dapat menciptakan kepuasan kerja sesama karyawan, menjadi mampu menciptakan satu upaya untuk mempertahankan organisasinya Dinas Pariwisata melakukan suatu acara resmi dalam 5 tahun sekali dimana seluruh karyawan pada beri penghargaan atas dedikasi pekerjaan yang dilakukan yaitu berupa pemberian bonus pada pegawai yang bekerja diatas 10 tahun, seperti yang ungkapkan oleh Rahmat, S.Sos selaku kepala dinas Pariwisata kabupaten Mamasa bahwa :

"Seluruh pegawai akan diberikan penghargaan atas dedikasinya dan pengapdianya selama bekerja di dinas pariwisata kabupaten mamasa, tetapi hadia penghargaan ini akan diberikan kepada karyawan berdasarkan jabatan dan lamanya,ini adalah kegiatan rutin yang dilakukan sekali dalam 5 tahun untuk menaikkan semangat kerja staf atau pegawai dalm bekerjakarena dengan melakukan ini akan ada kepuasan kerja para karyawan dan pastinuya akan ada peningkatan dan tujian akan tercapai" (Wawancara, 9 Juni 2020)

Dari pernyataan di atas dapat diartikan bahwa dalam melakukan rancangan seperti penetapan gaji tambahan atau intensif kepada pegawai dari jabatan dan alamanya bekerja dapat meningkatkan semangat kerja pegawai ataupun staf karena adanya hal ini maka semua pegawai akan semakin termotivasi untuk bekerja dan menunjukkan performa terbaik mereka dan dengan begitu Dinas Pariwisata dapat tetap berkiprah dan bersaing dengan dinas atau instansi lain yang terdapat di sulawesi barat.

Dari penelitian ini hasil yang didapat searah dengan menggunakan landasan teori komunikasi organisasi yaitu pada penelitian ini total ada empat langkah atau step komunikasi yakni komunkasi secara formal, secara informal, struktural, dan kekeluargaan.Dimana komunikasi formal terdapat model serta pengaruh komunikasi rantai yang dilakukan dalam lingkup dinas pariwisata kabupaten mamasa yang ingin berkomunikasi dengan lepala dinas harus melalui sekretaris sebelum kepala dinas langsung dan empat langkah dalam berkomunikasi dapat meningkatkan kepercayaan diri yang dilakukan oleh pemimpin dan staf dinas pariwisata kabupaten mamasa.

\section{Hambatan Komunikasi Terhadap hubungan Kinerja Pegawai Dinas Pariwisata Kabupaten Mamasa}

Hubungan adalah hal yang sudah biasa yang bisa dijumpai bagi setiap manusia. Apakah itu berdasarkan diri sendiri, atau sesuai lingkungan sosial maupun masyarakat luas. Sebelum penulis menjelasakan hambatan dalam komunikasi pimpinan terhadap kinerja pegawai Dinas Pariwisata Kabupaten mamasa, terlebih dahulu penulis mengungkapkan beberapa faktor pendukung 
komunikasi pimpinan Terhadap pekerjaan pegawai Dinas Pariwisata Kabupaten Mamasa.

Sebagai mahluk sosial manusia wajib berkomunikasi, artinya kita manusia memerlukan manusia lainnya atau kelompok buat saling berinteraksi, hal ini sudah menjadi ketetapan,ini merupakan sebuah ketetapan bahwa sebagian besar manusia ada berdasarkan output integrasi sosial dengan sesama pada kelompok atau instansi yang ada.di dalam kelompok atau instansi selalu ada bentuk kepemimpinan yang adalah faktor krusial buat kelangsungan hidup kelompok yang terdiri menurut atasan dan bawahannya,oleh karena itu komunikasi kelompok yang baik bisa menjadi pemicu keberhasilan suatu organisasi.

\section{KESIMPULAN}

Berdasarkan hasil penelitian yang penulis lakukan, maka dapat disimpulkan bahwa, pola komunikasi pimpinan terhadap kinerja pegawai Dinas Pariwisata Kabupaten Mamasa dengan menggunakan pola komunikasi formal dan secara struktural. Komunikasi formal merupakan suatu proses komunikasi yang bersifat resmi dan umumnya dilakukan di dalam forum formal melalui garis perintah. Sedangkan komunikasi struktural adalah proses komunikasi yang dilakukan secara sturuktural dengan adanya tahapan pada pengambilan keputusan menggunakan rapat kerja supaya acara-acara kerja dapat terelealisasikan dengan baik sehingga tidak terjadi miss communication dan tujuan utama mampu tercapai.

\section{DAFTAR PUSTAKA}

Arni Muhammad. 2007. Komunikasi Organisasi. Jakarta: PT Bumi Aksara, h. $2^{5}$ Angriana, Widya Resky. 2018. Pengaruh Komunikasi Organisasi Terhadap Motivasi Kerja Pegawai pada Kantor Kecamatan Tallo Kota Makassar: UIN Alaudin Makassar.

Barus, Evi Rahmi. 2010. Hubungan antaraKomunikasi Interpersonal, terhadap KinerjaTenaga Pendidik di SNMP 9 Pekanbaru. Pekanbaru: UNRI (tesis).

Bandung Hasibuan. 2007. "Manajemen Sumber Daya Manusia", Penerbit BumiAksara, Jakarta,

Cahyono, Hery Bambang. 2018. Pola Komunikasi Dinas Pariwisata Pemerintahan Daerah Kabupaten Banyuwangi dalam Mengembangkan Potensi Pariwisata Melalui Kegiatan Festifal: Universitas Muhammad Jember 
Hubungan Komunikasi Organisasi Antar Pegawai terhadap Kinerja Pegawai Dinas Pariwisata Kabupaten Mamasa

Sutrisno. Edy. 2011. Budaya Organisasi. Jakarta: Kencana,

Onong, Uchjana Effendy. 2005, Ilmu Komunikasi Teoridan Praktek. Bandung :PT Remaja Rosdakarya.

Emilia, Dkk. 2006, Modul Pelatihan Keterampilan Presentasi, Yogyakarta: UGM (http://ppkb.ugm.ac.id/pdf/Guidelines/modulbassindonesia.pdf)

Romli, Khomsahrial. 2011. Komunikasi Organisasi. Jakarta: Grafindo.

Remanda, Fariz. 2012. Pengaruh Komunikasi Interpersonal Terhadap Kinerja Pegawai Dinas Pekerjaan Umum Kota Pekanbaru: UIN (Skripsi)

Usman, Beny. 2013. Pengaruh Komunikasi Interpersonal Terhadap Kinerja Pegawai Pada Fakultas Ekonomi Universitas PGRI Palembang

Wirawan. 2008. Evaluasi Kinerja Sumber Daya Manusia; Teori, Aplikasi danPenelitian. Jakarta: Salemba Empat.

Pranata, Yogi Aditya. 2018. Model Komunikasi Dinas Pariwisata Surakarta Dengan Pelaku Usaha Dan Mui Dalam Pengembangan Halal Tourism Di Kota Surakarta : IAIN (Skripsi)

Profil Dinas Pariwisata Kabupaten Mamasa.2020

Risqi, Amin Baktiar. 2013. Efektifitas Komunikasi Santri Melalui Media Facebook Tentang Ilmu Keagamaan Di Pondok Pesantren Al Luqmaniyyah Yogyakarta : UIN Sunan Kalijaga (Skripsi)

Sari, Nova Serliana. 2013. Model Komunikasi Dalam Mengembangkan Image Obyek Wisata alam Oleh Humas Dinas Kebudayaan, Pariwisata, Pemuda dan Olahraga kab.rokam hilir : UIN Syarif Kasim Pekanbaru Riau Proses Komunikasi, (http://www.dim.esdm.go.id/makalah/PrOsesKomNew.pdf)

Suranto AW, 2006, Komunikasi Efektif Untuk Mendukung Kinerja Perkantoran (http://www.google.com/komunikasi/2006)

Rakhmat, Jalaluddin. 1993. Psikologi Komunikasi. Bandung: PT. Remaja Rosdakarya.

Suranto AW, 2006, Komunikasi Efektif Untuk Mendukung Kinerja Perkantoran (http://www.google.com/komunikasi/2006)

Sembel, Roy PhD, 2005, Bagaimana Membangun Komunikasi Dua Arah, (http://www.wordpress.com. 